[18]安岡式水中撮影法の効果

有馬研究所 安岡徳次郎

（第 3 回総会発表）

〔19〕レントゲン線による複写法

京都府立医大 酒 井 正 啓

(第 2 回総会発表)

[20] X 線フィルムの反転現像

神戸川崎病院 岡橋房 -

$\mathrm{X}$ 線フィルムの現像には殆んどが陰画処理であるが， てれを陽画にするため, 反転現像法を行ってみたとし ろ，非常に好結果を得たので報告した。即ち胸部骨関 係等に於ては充分診断し得られるものが出来だ，実験 方法として, (1)曝写, (2)第一現像, (3)漂白, (4)清浄, (5)露光，(6)第二現像，(7)定着.

（第 8 回総会発表）

\section{〔21〕 X線による淂画製作法に就いて}

名古屋大学医学部 奥村彦太郎

最近学会及び教材用として「スライド」が広く使用 されるようになり，ネガフィルム（ライカ判）よりポ シに焼付けるのには技術的困難なため増感紙を用いて 簡単に焼付ける方法及び增感紙を用い X-RAY フィ ルムペーパー等に（陽画・絵画）焼付ける方法を報告

(第 8 回総会発表)

\section{禾壶類のレ線照射に依る影響に就いて}

(中間発表)

松江農林放射線科学研究所 木村謙介 本実験は各方面に於て，種々論議されつつあるも， 過去の交献も古く（1896年）又我国にても，山田，中 村，小室，佐伯，早矢仕等の業績幾多ある，余等は昭 和 8 年より昭和 25 年まで引続き種子にX 線照射の実験 的研究をなしつつあった。余等の今回報告せんとする 問題は，未だ他に報告を知らない，種子を各種元素溶 夜に浸漬なしたるものにX楾照射を与え，発芽成育状 沙を観察したるものである．てれを考察するに各種子 に附着したる各元素は X線照射に対し同位元素的何等 かの影響をもつものと考えられるので，その成績の一 端を報告した。

（第 4 回総会発表）
〔23〕 X 線の水稲に及ぼす影響に就いて（第 1 報）

松江農林放射線科学研究所木村謙介

門脇䇅久

レ線が水稻の種子の発芽，生育に及ばす影響，苗代 期生育状況, 本田插种後育生状況成熟期の状況, 収量 に及ぼす影響等について行ってきた研究の結果を報告 した。

（第 4 巻第 $1 \cdot 2$ 号掲載）

〔24】禾穀類の $X$ 線照射に依る影響に就て（第2報） 松江農林放射線科学研究所木村謙介

門脇義 久

余等は昭和 8 年以降, 引続き植物種子にX線照射の 実験的研究を行ってきたが，今回は種々なる元素の溶 液に種子を浸漬し，更に乾燥してX線照射を行いその 影響と乾燥種子と含水せる種子との比較実験を行った ので報告した。

（第 4 巻第 3 号揭载）

[25]エックス線が妾, 金時豆, 落花生, 大豆等に 及ぼす影響に関する研究

国立徳島療養所 阿部通夫

「或る一定の照射条件の下に」X線をモるに照射す ると米 $43 \%$ の増収可能であるという報道に対し，筆者 の行ってきた麦, 金時豆, 落花生, 大豆等に照射して 或る程度の結果を得ているのでその実験結果を報告し た.

（第 4 巻第 $1 \cdot 2$ 号掲载）

〔26]過去 5 カ年間に経験せるレ線フィルム失敗の 統計的観察に就いて

国立久留米病院 吉 泉 元治

上野哲郎・寺崎郁子

レ線フィルム失敗の原因に就いては色々挙げられて いるが，一番多い原因は何か。レ線撮影技術の健全な 発展を希望し，失敗の原因を極力少くしたいと念願し 5 力年間の失敗の統計的観察を行いその結果失敗の原 因是正に努力し年々失敗数が減少してゆく傾向を示す に至ったので報告した。即ち 5 カ年間に撮影した枚数 は 53,500 枚失敗した枚数は 890 枚で 1.6\%にあたり， その原因は技師の撮影時の失敗よりも医師の連絡不充 分による原因が多い事を強調した。

(第 9.回総会発表) 